\title{
How the Calvin Hayes Review is Wrong about Libertarianism
}

\section{J. C. Lester}

This is a reply to the Calvin Hayes review (the review) of Escape from Leviathan (EfL). ${ }^{1}$ It is true that $E f L$ "is divided into four parts: Rationality, Liberty, Welfare and Anarchy". It is inaccurate to add, "based on what $[E f L]$ terms "preference utility". To be clear, EfL does use and defend a preferenceutilitarian conception of welfare: we are better off to the extent that our overall preferences, or wants, are satisfied. The theories of rationality, liberty, and anarchy, are not "based" on preference utility, although they are related to it in various ways. For the benefit of any welfare-essentialists who insist that want-satisfaction cannot be a type of welfare (even when we want our welfare to be judged that way, and even though preference utilitarianism exists), the main point is that - contrary to the typical statist view-liberty and private-property anarchy maximise want-satisfaction. However, EfL also defends this as a modus vivendi view of welfare that avoids conflict: primarily, the conflict that is caused by states coercively imposing things based on theories of welfare that flout people's actual preferences.

The review continues that EfL "begins with an extremely provocative quote: 'the only thing seriously wrong with they [sic] world is politics'". EfL does not itself have a quotation there. And the quoted sentence should read, "There is only one thing that is seriously morally wrong with the world, and that is politics" (opening sentence; emphasis added on missing word). As we shall see, this misquotation leads the review into some trouble later. This is an opportune place to emphasise that what EfL alludes to here are potential major and general contenders for what is "seriously morally wrong with the world", such as capitalism, socialism, patriarchy, religion (or its absence), environmental degradation, and so forth. It does not imply, of course, that there is nothing morally wrong with everyday individual acts of theft, fraud, assault, and so on (or, even less plausibly, that the state is morally responsible for all of these; although its existence does tend to make some of them more likely).

$E f L$ does argue, as the review notes, that liberty is compatible with welfare. But, just to be clear, also with relevant plausible theories of rationality and anarchy (compatible both conceptually and in practice); hence the subtitle of the original book. It is not correct to say that EfL "rejects both natural rights and contractarian position[s]": it is simply not engaged in a moral defence of libertarianism. (And although critical-rationalist epistemology implies that neither of these positions can give a 'supporting justification' to libertarianism, it does seem possible to make some sense of both of them in a nonjustificationist way.)

The review regards the idea that law and order can be private as 'the Achilles' heel of [EfL's] entire argument". Unfortunately, it does not offer any specific criticism of libertarian law and order or of the limited arguments about it in EfL. Therefore, there is nothing substantive to which to reply. And, as the review rightly notes at the outset, EfL's focus is on the philosophy (there is too much relevant non-philosophical work to explain it all). But some of the more-empirical works on this subject ${ }^{2}$ are cited by $E f L$ without any attempt to summarise their arguments.

It is not that human welfare (in preference-utilitarian terms) "entails ... anarchy": EfL does not attempt to derive anarchy from welfare. Rather, EfL argues that there is no sound reason to think that private-property anarchy conflicts with such welfare. And EfL does not argue that it is liberty that "rules out the pursuit of either so-called Social Justice (as in Rawls and numerous others) or Welfare (as defined by the "Welfare State' ..."). Rather, "Social Justice" and "Welfare" thus conceived are, first and foremost, self-defeating as regards welfare (but also incompatible with liberty and anarchy).

It is hard to understand how EfL's view of anarchy "ironically" puts it "into the company of ... the truly extreme left, the anarchists, who see the state as the instrument of the rich and privileged to keep their power at the expense of the poor and the working class". For one thing, anarcholibertarianism is indubitably on the "extreme left" in the pristine sense of the French National Assembly, whence the term originated. There those on the left were bourgeois and liberal as opposed to the right-

\footnotetext{
${ }^{1}$ Hayes, Calvin. "Libertarianism, Egalitarianism and The Open Society: Why Hacohen and Lester are both wrong about the Open Society". Bravenet: http://pub19.bravenet.com/forum/fetch.php?id=9899113\&usernum=1573050381

${ }^{2}$ Such as, Benson, Bruce L. The Enterprise of Law: Justice without the State (San Francisco: Pacific Research Institute for Public Policy, 1990), and To Serve and Protect: Privatization and Community in Criminal Justice (New York and London: New York University Press, 1998).
} 
wingers that were aristocratic and paternalistic. For another thing, EfL and many libertarians do indeed "see the state as the instrument of the rich and privileged to keep their power at the expense of the poor and the working class". For a third thing, while both types of anarchist want the state abolished, there is no serious similarity between the two societies that the opposing types of anarchist advocate to replace it. Is it "ironic" that two people who hate the same thing do not want the same alternative to it?

The review is "not convinced" that $E f L$ has "answered the crucial question for anarchists (which [non-anarchist] libertarians do not face) 'Will the Invisible Hand work in Hobbes' state of Nature?'" Why is "Hobbes' state of nature"3 still plausible? As mentioned in EfL (e.g., p.195 and note 72), game theory, social science, and biology now seem to explain cogently how cooperation (motivated by selfinterest yet promoting the common good: also known, following Adam Smith, as the "Invisible Hand") often arises spontaneously — even among different species — as long as there are iterated interactions. ${ }^{4}$ There would still be aggression and cheating, but this could be considerably ameliorated by competing private policing and legal systems (again, operating efficiently as though moved by an invisible hand) that are far better than the initiatedly-imposed monopoly of state law and order. Without a more engaged criticism, there is insufficient usefully to respond further.

Ultimately, the review wants to "agree with the libertarians on the basic rationale for the state viz. the Harm principle NOT Social justice is the only acceptable rationale for state coercion". But some libertarian views clearly hold that there is no "acceptable rationale for state coercion". And, as EfL explains (p.60), harm cannot be the thing to be avoided. Harm - understood as objective damage to our person or property - must be acceptable if it, or even the risk of it, is voluntarily accepted. Only initiatedly-imposed (inflicted) harm is unlibertarian. But then initiatedly-imposed 'help', such as a state ban on some objectively unhealthy activity, is unlibertarian too. Therefore, harm as such is irrelevant. It is only the initiated imposition of any unwanted thing that is proscribed by libertarianism. And, again, "Social Justice" (as normally interpreted) not only damages liberty but also the very human welfare that it is supposed to be promoting.

Now the earlier misquotation leads to trouble. We are told that "there are at least three sources of problems in the world not due to politics, that therefore it is incorrect to claim that the only thing seriously wrong with the world is politics. First there is Mother Nature; second there is Moral Hazard; third there is Market Failure". Unless the review implies that "Mother Nature" is literally a person of some kind, then nature cannot be "morally" at fault (as, we have seen, the corrected quotation requires). The idea of "Moral Hazard" is that it is possible to cause people to do more of some undesirable thing by the very attempt to protect them from the likelihood or consequences of its happening. Whether a moral issue or not, how is this a serious problem for non-political arrangements? (While the National Health Service, for instance, is clearly a moral hazard to health because it is free at the point of consumption irrespective of the person's past behaviour or any tax-extortion paid.) And what supposed "Market Failure"? Again, whether a moral issue or not, there is a wealth of libertarian literature explaining how the so-called 'market failures' are in reality state failures, caused by state interference with private property and competition (sundry examples crop up in EfL). Without any more-specific examples of alleged "Moral Hazard" and "Market Failure" it is not useful to elaborate.

Finally, the review asks, "How do we bring about a Utopia whether libertarian, egalitarian or both? We can choose [Vladimir] Lenin's method of coercion and thereby totally compromise the ideals or [John] Lennon's more peaceful persuasive method and sacrifice any hope of ever realizing the Utopia”. There are various errors in this quoted sentence and in the review's following text. Anarcholibertarianism is a utopia in the sense that it does not currently exist. It is not a utopia in the sense that it has never existed (as the review erroneously asserts), as shown by the examples of ancient Iceland ${ }^{5}$ and Ireland, ${ }^{6}$ for instance. And, although small by today's standards, these were not "small communities" as the review supposes any real examples must be. In any case, the historical absence of

\footnotetext{
${ }^{3}$ I.e., "during the time men live without a common power to keep them all in awe, they are in that condition which is called war; and such a war as is of every man against every man". Leviathan, Chap. 1.13.

${ }^{4}$ See, for instance, Axelrod, Robert M. The Evolution of Cooperation (New York: Basic Books, 1984).

${ }^{5}$ As championed, for instance, in Friedman, David D. The Machinery of Freedom: Guide to a Radical Capitalism, 2nd ed. (La Salle, Ill.: Open Court, 1989).

${ }^{6}$ As championed, for instance, in Rothbard, Murray N. For a New Liberty: The Libertarian Manifesto, rev. ed. (New York: Macmillan Co., 1978).
} 
something is hardly a proof of its impossibility. To say that we cannot have something new is to deny progress, or even change, entirely. Neither is anarcho-libertarianism a utopia in the sense that it is supposed to be a "perfect society", as the review puts it (without crime or defensive force, for instance). The review then asserts that the anarcho-libertarian utopia is "unrealizable" and that the "liberal democratic welfare state is a lesser evil than anarchy or authoritarian regimes of either 'right' or 'left" " because of "[i]mperfect people". However, unlike some socialist or communitarian anarchists, libertarians do not suppose that people will become, or need to become, better (let alone 'perfect') because the state is abolished. Private law and order will be necessary, and - there are many arguments to explain - much more efficient. The way to "bring about" this "Utopia" is to keep depoliticising until there is no political aggression left. This first requires convincing a critical mass of intellectuals that each next step, not the whole journey, is possible and desirable. That is, anarcho-libertarianism needs to use the very "peaceful persuasive method" that the review asserts, without explanation, must "sacrifice any hope of ever realizing the Utopia".

The review cites the "Open Society" twice in its title — and is clearly pro-Popperian-but then fails to mention the fourteen-point list, and surrounding discussion, that explicitly compares Popper's critical rationalism with anarcho-libertarianism (strong similarities) and liberal democracy (strong dissimilarities); $E f L$, pp.135-142. If the review had engaged more closely with the arguments of EfL and been more informed by the relevant social scientific literature, then it would probably have found the anarcho-libertarian case to be far more robust and realistic than such a cursory dismissal can hope to refute.

(February 2003; revised January 2022.) 